\title{
A case of $A L K$-rearranged non-small cell lung cancer that responded to ceritinib after development of resistance to alectinib
}

\author{
Yosuke Makuuchi ${ }^{1,2}$, Hidetoshi Hayashi ${ }^{1}$, Koji Haratani ${ }^{1}$, Junko Tanizaki ${ }^{1}$, Kaoru \\ Tanaka ${ }^{1}$, Masayuki Takeda ${ }^{1}$, Kazuko Sakai ${ }^{3}$, Shigeki Shimizu ${ }^{4}$, Akihiko Ito ${ }^{4}$, Kazuto \\ Nishio $^{3}$ and Kazuhiko Nakagawa ${ }^{1}$ \\ ${ }^{1}$ Department of Medical Oncology, Kindai University Faculty of Medicine, Osaka-Sayama, Osaka 589-8511, Japan \\ ${ }^{2}$ Department of Hematology, Graduate School of Medicine, Osaka City University, Abeno, Osaka 545-8585, Japan \\ ${ }^{3}$ Department of Genome Biology, Kindai University Faculty of Medicine, Osaka-Sayama, Osaka 589-8511, Japan \\ ${ }^{4}$ Department of Pathology, Kindai University Faculty of Medicine, Osaka-Sayama, Osaka 589-8511, Japan \\ Correspondence to: Hidetoshi Hayashi, email: hidet31@med.kindai.ac.jp \\ Keywords: non-small cell lung cancer (NSCLC); L1 196M; anaplastic lymphoma kinase (ALK) fusion gene; ceritinib; alectinib \\ Received: December 26, $2017 \quad$ Accepted: April 02, $2018 \quad$ Published: May 01, 2018
}

Copyright: Makuuchi et al. This is an open-access article distributed under the terms of the Creative Commons Attribution License 3.0 (CC BY 3.0), which permits unrestricted use, distribution, and reproduction in any medium, provided the original author and source are credited.

\section{ABSTRACT}

The second-generation anaplastic lymphoma kinase (ALK) tyrosine kinase inhibitors (TKIs) alectinib and ceritinib are standard treatment options for patients with non-small cell lung cancer (NSCLC) positive for ALK fusion genes. However, almost all patients eventually develop resistance to these drugs. We here report a case of $A L K$-rearranged NSCLC that developed resistance to alectinib but remained sensitive to ceritinib. The L1196M mutation within the ALK fusion gene was detected after failure of consecutive treatment with crizotinib and alectinib, but no other mechanism underlying acquired resistance to ALK-TKIs was found to be operative. Given the increasing application of ALK-TKIs to the treatment of patients with $A L K$-rearranged NSCLC, further clinical evaluation is warranted to provide a better understanding of the mechanisms of acquired resistance to these agents and to inform treatment strategies for such tumors harboring secondary mutations.

\section{INTRODUCTION}

Rearrangements of the anaplastic lymphoma kinase (ALK) gene have been detected in $3 \%$ to $7 \%$ of non-small cell lung cancers (NSCLCs) $[1,2]$. Such tumors are oncogene addicted and are therefore usually sensitive to treatment with ALK tyrosine kinase inhibitors (TKIs). Alectinib (CH5424802) and ceritinib (LDK378) are highly selective second-generation ALKTKIs that have recently been developed to overcome acquired resistance to the first-generation ALK-TKIs crizotinib. Alectinib shows pronounced anticancer activity against $A L K$ fusion-positive NSCLC cells that harbor the most common crizotinib resistance mutations [3, 4]. It also reduced the risk of disease progression or death by $66 \%$ compared with crizotinib in a randomized phase III trial for ALK-TKI-naïve patients with $A L K$-rearranged NSCLC $[5,6]$. Despite its marked efficacy, however, almost all patients treated with alectinib eventually develop resistance to this drug, with no therapeutic strategy having been shown to be effective for overcoming such resistance. Ceritinib has also manifested robust efficacy in crizotinib-resistant patients, being associated with a median progression-free survival (PFS) of 5.4 months in a randomized phase III trial [7]. In addition, it has shown an efficacy similar to that of alectinib in ALK-TKI-naïve patients with $A L K$ rearranged NSCLC, with a median PFS of 16.6 months [8]. However, the efficacy of ceritinib for patients previously treated with alectinib has remained unknown. We here report a case of ALK-rearranged NSCLC that progressed after treatment with crizotinib and 
alectinib possibly due to L1196M secondary mutation, and subsequently manifested tumor shrinkage during treatment with ceritinib.

\section{CASE PRESENTATION}

A 58-year-old woman who was a light smoker was diagnosed with stage IIA adenocarcinoma of the left lung. The tumor was removed by surgical resection and was found to harbor an $A L K$ fusion gene without L1196M mutation by genomic analysis. Three years after surgery, the patient experienced disease recurrence as lung metastases. She was treated with 3 cycles of bevacizumab plus carboplatin and paclitaxel as a first-line drug treatment, following 22 cycles of bevacizumab and pemetrexed as the maintenance therapy, but 2 years later computed tomography (CT) again revealed progression of her pulmonary disease. Crizotinib was then administered $200 \mathrm{mg}$ twice daily and induced marked tumor regression with manageable toxicity for 19 months. Subsequent progression of lung metastases was followed by treatment with alectinib at $300 \mathrm{mg}$ twice daily, which yielded a partial response. Despite the emergence of multiple pulmonary metastases as revealed by CT at 8 months after the onset of alectinib treatment, the patient continued alectinib therapy for another 6 months beyond disease progression, given the manageable toxicity profile and slowly progression of disease. A bronchoscopic biopsy was performed to identify the genomic change underlying the acquired resistance of the lung metastases to alectinib. Targeted sequencing of DNA encoding the entire ALK kinase domain with the Ion AmpliSeq Colon and Lung Cancer Research Panel v2 (Life Technologies-Thermo Fisher Scientific, Waltham, MA, USA) revealed the L1196M mutation (Figure 1). Immunohistochemistry analysis showed no staining of phosphorylated Insulin-like growth-factor-1 receptor (IGF-1R) which is recognized as the resistance factor about alectinib. Alectinib was discontinued, and chemotherapy was commenced using nivolumab (3 mg/kg, 3-weekly for 4 cycles) followed by $60 \mathrm{mg} / \mathrm{m}^{2}$ of docetaxel for 1 cycle. Since there was no alternative treatment with tolerable toxicity, she was rechallenged with alectinib at $300 \mathrm{mg}$ twice daily for 2 months until disease progression. Five months after discontinuation of the initial alectinib treatment, CT again revealed progression of lung metastases (Figure 2A). Ceritinib was then administered at $750 \mathrm{mg}$ once daily. Although the patient experienced nausea and diarrhea that required a dose reduction to $450 \mathrm{mg}$ once daily, she was well managed with ceritinib and CT at 12 weeks after treatment onset revealed tumor regression (Figure 2B). After 30 weeks of ceritinib administration, however, CT showed that the lung metastases had again progressed (Figure 2C) and brain magnetic resonance imaging revealed brain metastasis.

\section{DISCUSSION}

We here describe a case of $A L K$-rearranged NSCLC that underwent disease progression during alectinib treatment, was found to harbor the L1196M mutation of ALK, and then showed a response to ceritinib treatment. Genomic analysis of the primary lung tumor both at diagnosis and after progression of alectinib revealed that the L1196M change was an acquired mutation with crizotinib or alectinib. $A L K$-rearranged NSCLC is initially sensitive to ALK-TKIs but eventually develops resistance to these drugs through various mechanisms. In general, these mechanisms fall into two classes: (1) genetic alterations of the $A L K$ fusion gene itself including secondary mutation and gene amplification, both of which limit the ability of the drugs to inhibit kinase activity; and (2) changes to alternative signaling pathways - such as those mediated by the epidermal growth factor receptor, c-KIT, or IGF-1R - that allow ALK-related signaling to be bypassed $[9,10]$. In the present case, we performed target sequencing and pathological evaluation with immunohistochemistry. We did not detect amplification of the $A L K$ fusion gene, any bypass track, or other secondary mutations such as 11171 or V1180L that are known to be associated with sensitivity to ceritinib and resistance to alectinib [11, 12] (data not shown), suggesting that, whereas the L1196M mutation within the ALK fusion gene confers resistance to alectinib, it might not affect sensitivity to ceritinib.

The most common secondary mutation in the kinase domain of $A L K$ fusion genes is the gatekeeper substitution L1196M [13]. Our report implied that the L1196M mutation in $A L K$-rearranged NSCLC is related to disease progression during alectinib treatment and ceritinib can overcome this resistance in the clinical setting. Clinical studies suggested that both of alectinib and ceritinib were effective in patients with $A L K$-rearranged NSCLC harboring L1196M mutation [14, 15]. More recently, in phase 2 Japanese clinical trial of ceritinib for alectinib resistance NSCLC, treatment of ceritinib achieved the tumor shrinkage for the patient harboring L1196M mutation [16]. ALK-rearranged NSCLC cell lines harboring various types of secondary $A L K$ mutations were recently assayed for sensitivity to ALK-TKIs in vitro [17]. In the case of cells expressing an $A L K$ fusion gene harboring the L1196M mutation, both crizotinib and alectinib showed lower potency in inhibiting ALK phosphorylation (median inhibitory concentrations of 339 and 117.6 $\mathrm{nM}$, respectively) than ceritinib $(9.3 \mathrm{nM})$. These results demonstrated that $A L K$ fusion gene harboring the L1196M mutation conferred higher level of resistance to crizotinib and alectinib than ceritinib. These preclinical results are thus consistent with the present case, which responded to ceritinib after failure of alectinib treatment and was found by a next-generation sequencing assay to harbor the L1196M mutation as the mechanism of resistance. 
In summary, we report a case of $A L K$-rearranged NSCLC that developed resistance to alectinib but remained sensitive to ceritinib. This case suggests that the
L1196M mutation contributed to the differential response to alectinib versus ceritinib. As far as we are aware, our report is the first to show that the L1196M mutation in

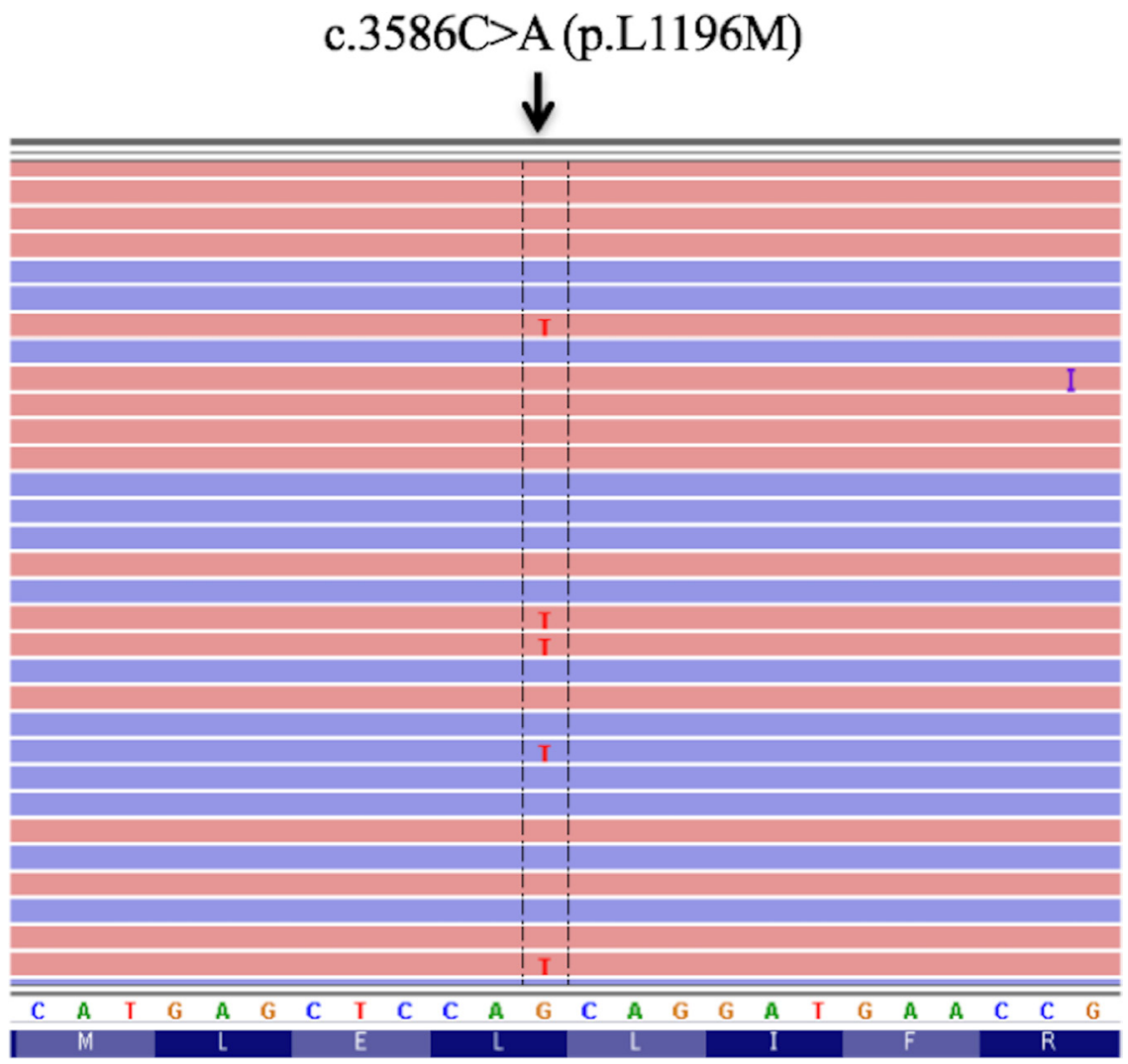

Figure 1: Sequence trace for cDNA encoding the L1196M mutation of the ALK kinase domain that was derived from the NSCLC of the patient.
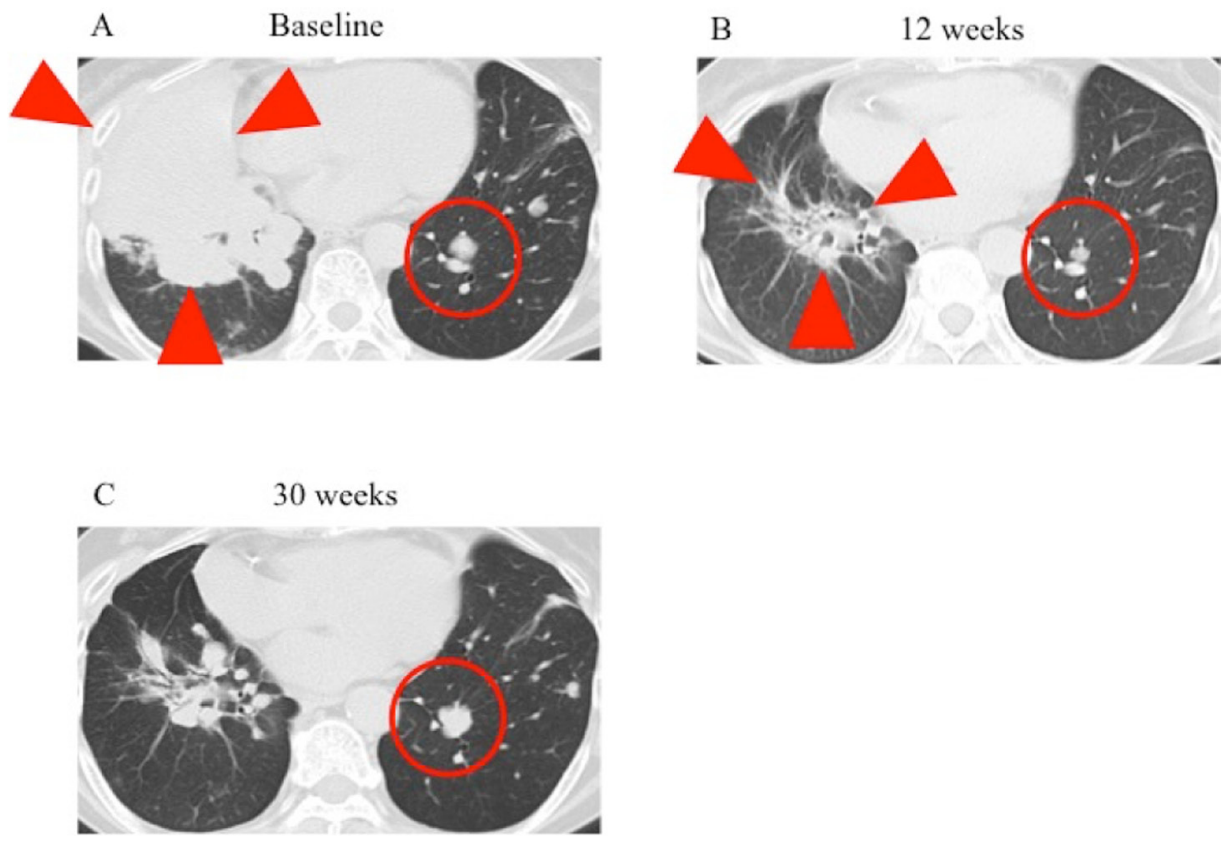

Figure 2: CT findings for the lung lesions of the patient during ceritinib treatment. CT scans of the lung lesions (red arrowheads and circles) were performed immediately before (A) as well as 12 (B) and 30 (C) weeks after the onset of ceritinib treatment. 
ALK-rearranged NSCLC is related to disease progression during alectinib treatment and that ceritinib can overcome this resistance in the clinical setting. Further studies are thus warranted to provide a better understanding of this phenomenon and to inform treatment strategies for $A L K$ rearranged NSCLC positive for secondary mutations after progression during alectinib treatment.

\section{Abbreviations}

ALK, anaplastic lymphoma kinase; TKI, tyrosine kinase inhibitor; NSCLC, non-small cell lung cancer; PFS, progression-free survival; CT, computed tomography; IGF-1R, insulin-like growth-factor-1 receptor.

\section{Author contributions}

YM, HH, KH, JT, KS and SS were responsible for clinical management of the patient, acquisition of data, and drafting the manuscript; KT, MT, AI, KN and KN were responsible for interpretation of data and critical revision of the manuscript. All authors read and approved the final manuscript.

\section{CONFLICTS OF INTEREST}

H.H. has received honoraria from AstraZeneca K.K., Boehringer Ingelheim Japan Inc., Bristol-Myers Squibb Co. Ltd., Eli Lilly Japan K.K., Ono Pharmaceutical Co. Ltd. and Taiho Pharmaceutical Co. Ltd.; and lecture fee from Chugai Pharmaceutical Co. Ltd., Kyowa Hakko Kirin Co. Ltd., MSD K.K. and Pfizer Japan Inc.; and research funding from Ono Pharmaceutical Co. Ltd. K.H. has received honoraria from Ono Pharmaceutical Co. Ltd. and lecture fee from Pfizer Japan Inc. K.T. has received lecture fee from AstraZeneca K.K. and Merck Serono Co. Ltd. K.N. has received honoraria from Astellas Pharma Inc., AstraZeneca K.K., AYUMI Pharmaceutical Corporation, Boehringer Ingelheim Japan Inc., Bristol-Myers Squibb Co. Ltd., Chugai Pharmaceutical Co. Ltd., Daiichi Sankyo Co. Ltd., Eli Lilly Japan K.K., Kissei Pharmaceutical Co. Ltd., Kyowa Hakko Kirin Co. Ltd., MSD K.K., Novartis Pharma K.K., Ono Pharmaceutical Co. Ltd., Pfizer Japan Inc., Showa Yakuhin Kako Co. Ltd., Sym Bio Pharmaceuticals Limited. and Taiho Pharmaceutical Co. Ltd.; and research funding from AbbVie Inc., Astellas Pharma Inc., AstraZeneca K.K., Boehringer Ingelheim Japan Inc., Bristol-Myers Squibb Co. Ltd., Daiichi Sankyo Co. Ltd., Eisai Co. Ltd., Eli Lilly Japan K.K., GlaxoSmithKline K.K., Kyowa Hakko Kirin Co. Ltd., Merck Serono Co. Ltd., MSD K.K., Novartis Pharma K.K., Ono Pharmaceutical Co. Ltd., Otsuka Pharmaceutical Co. Ltd., Pfizer Japan Inc., Taiho Pharmaceutical Co. Ltd., Takeda Pharmaceutical Co. Ltd. and Yakult Honsha Co. Ltd.; and consulting or advisory role for Astellas Pharma Inc., Eli Lilly Japan K.K. and Ono Pharmaceutical Co. Ltd. All other authors declare no potential conflicts of interest.

\section{FUNDING}

This work was supported by a Japan Society for the Promotion of Science KAKENHI grant number JP17K15032.

\section{REFERENCES}

1. Kwak EL, Bang YJ, Camidge DR, Shaw AT, Solomon B, Maki RG, Ou SH, Dezube BJ, Janne PA, Costa DB, VarellaGarcia M, Kim WH, Lynch TJ, et al. Anaplastic lymphoma kinase inhibition in non-small-cell lung cancer. N Engl J Med. 2010; 363:1693-703. https://doi.org/10.1056/ NEJMoa1006448.

2. Soda M, Choi YL, Enomoto M, Takada S, Yamashita Y, Ishikawa S, Fujiwara S, Watanabe H, Kurashina K, Hatanaka H, Bando M, Ohno S, Ishikawa Y, et al. Identification of the transforming EML4-ALK fusion gene in non-small-cell lung cancer. Nature. 2007; 448:561-6. https://doi.org/10.1038/nature05945.

3. Kodama T, Tsukaguchi T, Yoshida M, Kondoh O, Sakamoto H. Selective ALK inhibitor alectinib with potent antitumor activity in models of crizotinib resistance. Cancer Letters. 2014; 351:215-21. https://doi.org/10.1016/j. canlet.2014.05.020.

4. Sakamoto H, Tsukaguchi T, Hiroshima S, Kodama T, Kobayashi T, Fukami TA, Oikawa N, Tsukuda T, Ishii N, Aoki Y. CH5424802, a selective ALK inhibitor capable of blocking the resistant gatekeeper mutant. Cancer Cell. 2011; 19:679-90. https://doi.org/10.1016/j.ccr.2011.04.004.

5. Hida T, Nokihara H, Kondo M, Kim YH, Azuma K, Seto T, Takiguchi Y, Nishio M, Yoshioka H, Imamura F, Hotta K, Watanabe $\mathrm{S}$, Goto K, et al. Alectinib versus crizotinib in patients with ALK-positive non-small-cell lung cancer (J-ALEX): an open-label, randomised phase 3 trial. Lancet. 2017; 390:29-39. https://doi.org/10.1016/s0140-6736(17)30565-2.

6. Peters S, Camidge DR, Shaw AT, Gadgeel S, Ahn JS, Kim DW, Ou SI, Perol M, Dziadziuszko R, Rosell R, Zeaiter A, Mitry E, Golding S, et al. Alectinib versus Crizotinib in Untreated ALK-Positive Non-Small-Cell Lung Cancer. N Engl J Med. 2017; 377:829-38. https://doi.org/10.1056/ NEJMoa1704795.

7. Shaw AT, Kim TM, Crinò L, Gridelli C, Kiura K, Liu G, Novello S, Bearz A, Gautschi O, Mok T, Nishio M, Scagliotti G, Spigel DR, et al. Ceritinib versus chemotherapy in patients with ALK-rearranged nonsmall-cell lung cancer previously given chemotherapy and crizotinib (ASCEND-5): a randomised, controlled, openlabel, phase 3 trial. Lancet Oncol. 2017; 18:874-86. https:// doi.org/10.1016/S1470-2045(17)30339-X.

8. Soria JC, Tan DSW, Chiari R, Wu YL, Paz-Ares L, Wolf J, Geater SL, Orlov S, Cortinovis D, Yu CJ, Hochmair $\mathrm{M}$, Cortot AB, Tsai CM, et al. First-line ceritinib versus platinum-based chemotherapy in advanced ALK-rearranged non-small-cell lung cancer (ASCEND-4): a randomised, 
open-label, phase 3 study. The Lancet. 2017; 389:917-29. https://doi.org/10.1016/S0140-6736(17)30123-X.

9. Doebele RC, Pilling AB, Aisner DL, Kutateladze TG, Le AT, Weickhardt AJ, Kondo KL, Linderman DJ, Heasley LE, Franklin WA, Varella-Garcia M, Camidge DR. Mechanisms of resistance to crizotinib in patients with ALK gene rearranged non-small cell lung cancer. Clin Cancer Res. 2012; 18:1472-82. https://doi.org/10.1158/1078-0432.ccr11-2906.

10. Katayama R, Shaw AT, Khan TM, Mino-Kenudson M, Solomon BJ, Halmos B, Jessop NA, Wain JC, Yeo AT, Benes C, Drew L, Saeh JC, Crosby K, et al. Mechanisms of acquired crizotinib resistance in ALK-rearranged lung Cancers. Sci Transl Med. 2012; 4:120ra17. https://doi. org/10.1126/scitranslmed.3003316.

11. Ou SH, Greenbowe J, Khan ZU, Azada MC, Ross JS, Stevens PJ, Ali SM, Miller VA, Gitlitz B. I1171 missense mutation (particularly $\mathrm{I} 1171 \mathrm{~N}$ ) is a common resistance mutation in ALK-positive NSCLC patients who have progressive disease while on alectinib and is sensitive to ceritinib. Lung Cancer. 2015; 88:231-4. https://doi. org/10.1016/j.lungcan.2015.02.005.

12. Katayama R, Friboulet L, Koike S, Lockerman EL, Khan TM, Gainor JF, Iafrate AJ, Takeuchi K, Taiji M, Okuno Y, Fujita N, Engelman JA, Shaw AT. Two novel ALK mutations mediate acquired resistance to the next-generation ALK inhibitor alectinib. Clin Cancer Res. 2014; 20:568696. https://doi.org/10.1158/1078-0432.ccr-14-1511.

13. Choi YL, Soda M, Yamashita Y, Ueno T, Takashima J, Nakajima T, Yatabe Y, Takeuchi K, Hamada T, Haruta H, Ishikawa Y, Kimura H, Mitsudomi T, et al. EML4-ALK mutations in lung cancer that confer resistance to ALK inhibitors. N Engl J Med. 2010; 363:1734-9. https://doi. org/10.1056/NEJMoa1007478.

14. Puig O, Yang JCH, Ou SHI, Chiappori A, Chao BH, Belani CP, Spira AI, Bearz A, Duruisseaux M, Allard J, Birzele F, Boisserie F, Lonngren U, et al. Pooled mutation analysis for the NP28673 and NP28761 studies of alectinib in ALK + non-small-cell lung cancer (NSCLC). Journal of Clinical Oncology. 2016; 34:9061. https://doi.org/10.1200/ JCO.2016.34.15_suppl.9061.

15. Tan DSW, Kim DW, Thomas M, Pantano S, Wang Y, Szpakowski SL, Yovine AJ, Mehra R, Chow LQ, Sharma S, Solomon BJ, Felip E, Camidge DR, et al. Genetic landscape of ALK+ non-small cell lung cancer (NSCLC) patients (pts) and response to ceritinib in ASCEND-1. Journal of Clinical Oncology. 2016; 34:9064. https://doi.org/10.1200/ JCO.2016.34.15_suppl.9064.

16. Horinouchi H, Maemondo M, Hida T, Takeda M, Hotta K, Hirai F, Kim Y, Matsumoto S, Mitsudomi T, Seto T, Moizumi S, Tokushige K, Hatano B, et al. P1.03-005 Phase 2 Study of Ceritinib in Patients with ALK+NSCLC with Prior Alectinib Treatment in Japan: ASCEND-9. Journal of Thoracic Oncology. 2017; 12:S1952-S1953. https://doi. org/10.1016/j.jtho.2017.09.809.

17. Gainor JF, Dardaei L, Yoda S, Friboulet L, Leshchiner I, Katayama R, Dagogo-Jack I, Gadgeel S, Schultz K, Singh M, Chin E, Parks M, Lee D, et al. Molecular Mechanisms of Resistance to First- and Second-Generation ALK Inhibitors in ALK-Rearranged Lung Cancer. Cancer Discov. 2016; 6:1118-33. https://doi.org/10.1158/2159-8290.cd-16-0596. 